\title{
Green Supply Chain Research in China Steel Industry
}

\author{
Meiyan Wang ${ }^{1, a}$ \\ University of Science and Technology LiaoNing, China \\ 358147220@qq.com
}

Keywords: iron and steel industry, green supply chain ,strategic cooperation

Abstract. Iron and steel industry, as the important foundation of the national economy, has been developed rapidly in recent years. However, with constant expansion of steel production, industrial emissions and pollution problem is increasingly outstanding, the previous extensive development mode cannot adapt to the modern iron and steel industry demand. How to reduce the emission pollution, energy consumption, and develop the green steel economy, have become the important subjects that iron and steel enterprises are facing.

\section{Introduction}

The world is facing energy shortage, environmental degradation and other issues. Our country's energy consumption is big, China is one of the major industrial countries too. At present, China's steel industry is still extensive mode of production, economic growth is mainly dependent on resource efficiency to achieve good high consumption. China's steel manufacturing industry is facing the dual pressures from environmental protection on the one hand, the pressure requirements of low-carbon economy. On the other hand, the pressure from the cost control, the shortage of raw materials, the prices high has become a bottleneck restricting the development of the steel industry, a serious threat to the sustainable development of the steel industry. Competitive steel companies, not only make the quality and price as the center, but also pay more attention to environmental performance, economic performance and sustainable development, and many other factors .

Green supply chain improved the traditional supply chain management, which requires consideration and strengthening of environmental factors in the supply chain management: through cooperation with internal upstream and downstream enterprises and communication in itself, to get the overall efficiency optimization from product design, material selection, manufacturing, product sales to the recovery of the whole process .

Iron and steel enterprises in the new environment would like to get some new breakthroughs and new development, we must build steel companies' "resources - products - waste --- renewable resources," repeated cycle of material flow and other green supply chain structure, to explore a steel manufacturing industry's recycling and sustainable green development, which is low-input, high output, low consumption, low emissions.

\section{Connotation of steel companies'green supply chain}

Green procurement includes corporate procurement process that involves access to raw materials, the supplier selection, evaluation, operations, within the distribution, and packaging. For the steel industry, an important part of the implementation of green procurement is the raw materials' recycling, strengthen cooperation with suppliers ,other related industries and society, expansion of eco-industrial chain.

Green production activities are the core competitiveness of steel companies in which it requests 
taken into account throughout the life cycle of the green from product design to the final stage of recovery. Green production targets at energy conservation, energy, pollution reduction. The production and the ecological environment, the combination of economic interests, thereby forming a truly green development model based on the production of a clean environment is.

Through Green production to attain the supply chain nodes are streamlined and efficient, dynamic, fast combination with business processes, to achieve economic efficiency of enterprises continuing grow, and optimize coordination in the social economy.

Green distribution is the logistics in the process from the enterprise to customers, including green packaging, pollution-free merchandise management and promotion of energy-commodity trading and distribution and so on. Green distribution is the end of the entire distribution supply chain and the ultimate realization of the value of the product, including a focus on the rationalization of distribution, control resource consumption, transport route optimization and other components.

Currently, China's iron and steel enterprises lagged behind those more developed countries in terms of storage and transport level. Many enterprises have not really realized that logistics is the third profit source of enterprises. Iron and steel enterprises should improve the logistics organization model, the popularity of low-carbon logistics concept, build intelligent transportation and warehousing systems, to save resources, reduce costs, improve management, get more profit.

Reverse logistics is an environmentally friendly method of reducing the use of resources. By recycling the material, original and return the product to the logistics chain, so as to effectively conserve resources, so that waste is reduced to a minimum.

For a long time, steel companies didn't pay much attention to build the reverse supply chain, resulted in increased business costs, low customer service levels, but also caused bad influence on the environment. In recent years, reverse supply chain is considered to be a new strategy to win business competition, is a major bright spot in the green supply chain, constitute a closed loop supply chain system with forward logistics .

Steel manufacturing's reverse supply chain involves a wide range, not only including the recycling of discarded products and packaging materials, but also including recycling and returns processing production of process waste and by-products. The purpose of Green recycling waste is to return them as a node on the enterprise supply chain which is hold by the end customer or the downstream business in the production and sales process through paid or unpaid, and according to the product structure and product characteristics and in various parts of performance to identify viable treatment options.

\section{China's iron and steel enterprises green supply chain optimization strategy}

Strengthen the strategic cooperation with external companies Development of the market presents new challenges for iron and steel enterprises green supply chain, such as the buyer of the global market, the increasingly demanding quality of technical content, customers emphasize personalized custom, more diverse demand for steel varieties and specifications . China's steel enterprises can be green in raw materials procurement,transport packaging of the products and product distribution only through the establishment of the green channel system.

?Select high-quality suppliers

To achieve strategic and external supply chain collaboration, iron and steel enterprises must carefully select partners upstream. We can learn from the leading foreign business practices: According to their own, environmental conditions and other factors to form the corresponding evaluation index system to scientific select suppliers by quantitative and qualitative analysis. This is just the beginning of a good first step in order to form a long-term win-win partnerships with 
suppliers. In future cooperation is not onlyt hrough monitoring and evaluation, but to give suppliers a number of substantive guidance and support. For example, delivery route optimization, improved raw materials' production processes and so on.

?The formation of steel companies' strategic alliances

Currently, in order to speed up industrial restructuring of iron and steel enterprises, to improve product competitiveness, Chinese steelmakers are in a new round of large-scale reorganization and integration. Break the boundaries of business, industry, geographical and other factors, the integration of procurement and distribution of resources and other aspects of the steel industry in order to promote sustainable development.

Through the establishment of iron and steel enterprises' strategic alliances, attain material flow of cross-organizational integration, integrate dispersed resources of strategic alliances, solve the bottleneck problem of iron and steel enterprises what are facing energy, raw materials and fuels, transportation and other aspects, build its stable sales channels, improve supply chain synergy operating speed. Risk sharing between partners, strengthen technological exchanges to maintain their competitive advantage in the separate market. Once the iron and steel enterprises establish strategic alliances, they will form a "competitive cooperation, cooperation in the competition" situation, and ultimately win-win situation.

Improve the internal core competitiveness China's steel enterprises green supply chain management is still in its infancy, mainly because the subject to many limitations of enterprise management level, technical strength, financial strength, environmental awareness. It requires that the industry should accelerate the transformation and upgrade of traditional manufacturing industries, to establish efficient, clean, low-carbon, recycling, green manufacturing system, and comprehensively improve the enterprise's core competitiveness.

Product upgrades, building recycling industry chain

Iron and steel enterprises should aim at zero emissions, establish three cycle chain after product upgrades.The first solid waste recycling chain, is to achieve metallurgical slag, iron zinc dust and mud, iron oxide and by-products of all solid waste recycling or safe disposal, form the group of a certain size, a high level of technical equipment, high solid waste comprehensive utilization rate of "zero discharge" enterprise; the second is the industrial water recycling chain,start metering from the enterprise supervision and management of water, press and comprehensively promote water quota, create conditions for the use of water, urban waste water, mine water and brackish water and other non-conventional water resources, improve waste recovery; the third is secondary recycling cycle chain of energy, promote energy-saving technologies, strengthen CDQ, waste heat recovery, the converter waste heat recovery, heat recovery steam recovery furnace work; improve and promote the transformation of air leakage, blast off the wet blast, gas and steam combined cycle power generation technology; the development of non-blast furnace slag waste heat recycling, reducing gas blast furnace injection and so on.

?ptimize processes, system integration

Green supply chain on the one hand to optimize the logistics chain, to promote non-supply of inventory management, reduce the cost of procurement management and warehousing costs. On the other hand to establish logistics network system which is compliance with the metallurgical industry, form a virtual network entity including metallurgy logistics network and logistics system line consisting of nodes, and logistics information system components and effective division of labor with social logistics network .

? Improve the logistics information platform, the development of green culture

Construction of the logistics information platform for the green supply chain management, , the use 
of automatic identification technology for real-time information collection, use of modern communications technology for real-time transmission of information, contact with enterprises upstream suppliers, downstream users and third-party logistics service and establish an integrated information management system.

Green supply chain is a long-term mechanism, so business managers must focus on the long-term interests of enterprises, establish full green concept, low-carbon into the corporate culture, build the green as a corporate image and brand. In order to gain advantage in the market competition and achieve sustained development,steel enterprises must establish environmental awareness, build a green brand and strengthen the construction of the human environment, so the green supply chain ,economic construction and real social goals should be together.

\section{Conclusion}

China's steel enterprises want to remain invincible in the fierce international competition, they must fully implement green supply chain management, mainly the following two aspects: First, improve core competitiveness within the enterprise, including product upgrades, process optimization, the pursuit of efficiency. Second, achieve strategic cooperation with external supply chain . On this basis, build a global logistics supply chain, participate in international operations, expand business the supply of raw materials and products for export channels.

In short, implementation of green supply chain management throughout the process of the purchase of raw materials, product design and manufacturing, sales, waste recycling, take the initiative to improve the sense of social responsibility and actively treat realize the whole green supply chain, to achieve economic, social and environmental benefits altogether.

\section{Acknowledgment}

First and foremost, I would like to show my deepest gratitude to Professor X.J. LU. Conversations with him have been most helpful. I shall extend my thanks to Mr. Ao for all his kindness and help. This work has been supported by The Applied school of University of Science and Technology Liaoning.

\section{References}

[1]Chunyu Xia , Green logistics [M] Beijing: China Logistics Publishing House, 2005 [2]Qinghua Zhu, Green Supply Chain Management [M] Beijing: Chemical Industry Press, 2004 [3]Zhigang Jiang, Strategy and steel enterprises to implement green manufacturing technology [J]. Metallurgical equipment, 2005 (4) 